\title{
Immunonephelometric Quantitation of Apolipoprotein E in Human Serum
}

\author{
By $P$. Weisweiler and $P$. Schwandt \\ with the technical assistance of Christine Friedl \\ Medical Department II, Grosshadern Clinic, University of Munich
}

(Received August 9/November 22, 1982)

Summary: A laser immunonephelometric procedure for the determination of apolipoprotein $\mathrm{E}$ in human serum and lipoprotein fractions was developed. Coefficients of variation were $2.3 \%$ within-run, $4.7 \%$ between-run. The distribution of apolipoprotein $\mathrm{E}$ in various lipoprotein fractions revealed a higher proportion of apolipoprotein E in VLDL in hypertriglyceridaemic subjects (especially marked in Type III patients) than in normal subjects. Laser immunonephelometry appears suitable for the routine measurement of apolipoprotein E.

\section{Immunonephelometrische Messung von Apolipoprotein $E$ in menschlichem Serum}

Zusammenfassung: Eine laserimmunonephelometrische Methode zur Bestimmung von Apolipoprotein $\mathrm{E}$ in menschlichem Serum und Lipoproteinfraktionen wurde entwickelt. Die Variationskoeffizienten waren 2,3\% (Intraassay) und 4,7\% (Interassay). Die Verteilung des an Lipoproteinen gebundenen Apolipoprotein E ergab einen höheren Anteil in den VLDL von Patienten mit einer Hypertriglyceridämie, besonders ausgeprägt bei der Typ III Hyperlipoproteinämie, als in den VLDL normaler Personen. Die Laserimmunonephelometrie erscheint geeignet für die Routinemessung von Apolipoprotein E.

\section{Introduction}

Apolipoprotein $\mathrm{E}$ has been reported to be an important constituent of normal human lipoproteins $(1,2)$. Its key role in the metabolism of chylomicron rem= nants and lipoproteins induced by cholesterol feeding was established in several species including humans. This apolipoprotein has been found to bind to apolipoprotein B receptors of extrahepatic cells and to hepatic receptors, thereby regulating the cholesterol uptake of the cells (3-6). The measurement of apolipoprotein $\mathrm{E}$ appears to be useful for judging the atherosclerotic risk more specifically $(7,8)$.

The concentration of apolipoprotein $\mathrm{E}$ in human serum and lipoprotein fractions has been determined by electroimmunoassay (9), by radial immunodiffusion (10), and by radioimmunoassay $(8,11-13)$. For serial measurements in epidemiological studies and general clinical use these methods are limited in capacity and time consuming. Immunonephelometry is a suitable alternative for the determination of serum proteins because of its relative simplicity, speed, and ease of automation (14). This report describes the development of a sensitive and specific immunoassay for apolipoprotein $\mathrm{E}$ using a laser nephelometer. The levels of apolipoprotein $E$ in serum and lipoprotein fractions were determined in normal and hyperlipoproteinaemic subjects.

\section{Materials and Methods}

\section{General procedures}

Serum samples from normal volunteers and hyperlipoproteinaemic patients (aged from 23 to 62 years), taking no medications and having fasted overnight, were analysed. Very low-density lipoproteins (VLDL, $d<1.006 \mathrm{~kg} / \mathrm{l}$ ) were separated from other lipoprotcins by preparative ultracentrifugation with a Beckman rotor 40.3 (15). Low-density and high-density lipoproteins were scparated by sodium phosphotungstate precipitation in the $d>1.006 \mathrm{~kg} /$ fraction (16). Cholesterol and triglycerides in se- 
rum and lipoprotcins were measured immediately by cnzymatic methods (Boehringer kits, Mannheim, FRG). Before assay of apolipoprotcin E. serum, VLDL, and the $\mathrm{d}>1.006 \mathrm{~kg} /$ fraction were stored at $-18^{\circ} \mathrm{C}$ for up to 2 months. The hyperlipoproteinaemic patients were classified according to the WHO criteria (17). Diagnosis of Type III hyperlipoproteinaemia was confirmed by analytical isoclectric focusing (18). All data are mean values $\pm \mathrm{SD}$. Correlations were made by linear regression analysis.

\section{Isolation of apolipoprotein $E$ and production of antiserum}

Apolipoprotein $\mathrm{E}$ was isolated from tetramethylurea-delipidated VLDL of hypertriglyceridaemic subjects by Sephacryl S 200 gel filtration and chromatofocusing as described (19). The homogeneity of apolipoprotein used as antigen and standard was assayed by polyacrylamide gel electrophoresis in sodium dodecyl sulphate (20). and by isoelectric focusing. The Lowry technique (21) was used for protein determination with bovine serum albumin as protein standard. Antisera to apolipoprotein $\mathrm{E}$ were produced by injecting rabbits subcutaneously on 3 occasions 14 days apart and bleeding them 7 days after the last injection. The total amount of antigen given per inoculation was $0.3 \mathrm{mg}$ apolipoprotein $\mathrm{E}$ dissolved in $0.05 \mathrm{ml} 0.01 \mathrm{~mol} / 1 \mathrm{NH}_{4} \mathrm{HCO}_{3}$ buffer, $\mathrm{pH} 8.6$, and emulsified in an equal volume of complete Freund's adjuvant '(Difco, Detroit, U.S.A.). The purity and specifity of the antiserum was checked by double immunodiffusion and immunoelectrophoresis using whole serum an'd purified apolipoprotein fractions.

The antiserum titer was determined by immunonephelometric titration. Serial dilutions of isolated apolipoprotein $\mathrm{E}$ dissolved in $0.01 \mathrm{~mol} / \mathrm{l}$ sodium phosphate buffer, $\mathrm{pH} 7.4$, were incubated with a 10 fold dilution of antiserum. Maximal light scattering was achieved with $0.91 \mathrm{~g} / 1$ apolipoprotein $\mathrm{E}$.

\section{Light scattering measurements}

We measured the light scattering produced by the antigen-antibody complex with a laser nephelometer (Behringwerke, Marburg. FRG). The apolipoprotein $E$ antiserum was diluted in the phosphate buffer. A 10 fold dilution of the filtered (Minisart ${ }^{R} P$, Sartorius, Göttingen, FRG, pore size $0.45 \mu \mathrm{m}$ ) antiserum was found to be optimal for routine analysis. Samples of serum and the $\mathrm{d}>1.006 \mathrm{~kg} /$ fraction were diluted 100 fold with phosphate buffer, containing $0.15 \mathrm{~mol}$ of $\mathrm{NaCl}, 40 \mathrm{~g}$ of polyethylene glycol 6000 (Serva, Heidelberg, FRG), and $0.15 \mathrm{ml}$ Tween $20^{\mathrm{R}}$ (Serva, Heidelberg, FRG) per liter. Usually, VLDL were delipidated with an equal volume of tetramethylurea and diluted 50 fold. The reaction mixture contained $0.2 \mathrm{ml}$ of diluted antiserum and $0.1 \mathrm{ml}$ of the diluted sample and was allowed to stand for $2 \mathrm{~h}$ at $23^{\circ} \mathrm{C}$. The apolipoprotein $\mathrm{E}$ concentration of serum and lipoprotein fractions was obtained from serial dilutions of isolated apolipoprotein $E$ in the sample buffer. The light scattering was plotted against the apolipoprotein $\mathrm{E}$ concentration to generate the standard curve from which the serum and lipoprotein apolipoprotein $\mathrm{E}$ concentrations could be determined.

\section{Apolipoprotein E quantitation by electroimmunoassay}

Rocket immunoelectrophoresis was done in $12.5 \mathrm{~g} /$ agarose plates using a $0.02 \mathrm{~mol} / \mathrm{l}$ barbital buffer, $\mathrm{pH} 8.6$, after adding $30 \mathrm{~g} / \mathrm{l}$ of apolipoprotein $\mathrm{E}$ antiserum at $52^{\circ} \mathrm{C}(22) .5 \mathrm{~mm}$ diameter holes for 15 samples were punched at the cathodal end. Serum samples were diluted 10 fold in barbital buffer. The apolipoprotein $\mathrm{E}$ concentration of serum and lipoprotein fractions was obtained from a standard curve of isolated apolipoprotein $E$ $(0.020-0.040 \mathrm{~g} /, 5$ points, $r=0.94)$. For staining Coomassie Blue R 250 (Serva, Heidelberg, FRG) was used. The height of the rockets was measured with a ruler to the nearest $0.5 \mathrm{~mm}$. The within-run coefficient of correlation (CV) was $1.6 \%$ (20 determinations). The day-to-day CV was $3.9 \%$ (15 days).

\section{Results}

\section{Analytical variables}

With detergent solution present the background light scattering was generally so low $(<3 \%)$ that it could be neglected up to a serum triglyceride concentration of $20.0 \mathrm{~g} / \mathrm{l}$. VLDL were delipidated with tetramethylurea prior to the assay without changing the immunoreactivity. The kinetics of the immune complex formation for isolated apolipoprotein $\mathrm{E}$ and apolipoprotein $\mathrm{E}$ present in serum and delipidated VLDL were identical, indicating similar exposure of the antigenic sites of apolipoprotein $\bar{E}$ (fig. 1). Maximal light scattering was reached after $2 \mathrm{~h}$ incubation at $23^{\circ} \mathrm{C}$. In a series of 20 aliquots of a quality control serum (mean apolipoprotein $\mathrm{E}$ concentration $0.091 \mathrm{~g} / \mathrm{l}$ ) the within-run $\mathrm{CV}$ was $2.3 \%$. The day-today $C V$ was $4.7 \%$ as measured during 15 consecutive days. The log-log standard curve of apolipoprotein $E$ was linear within the range of 0.020 to $0.400 \mathrm{~g} / \mathrm{l}$ apolipoprotein $\mathrm{E}$ (fig. 2). The lowest concentration that could be detected was $0.005 \mathrm{~g} / \mathrm{l}$ apolipoprotein E.

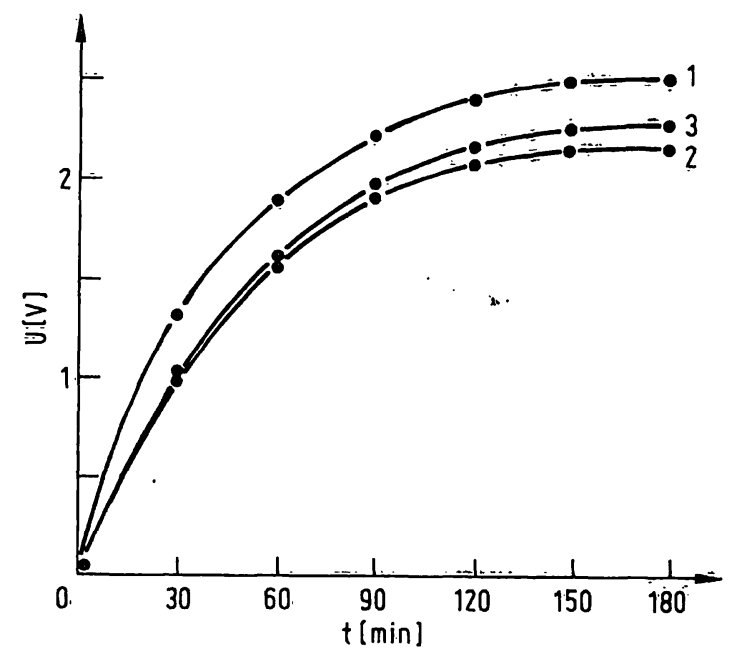

Fig. 1. Light scattering of the immunoreaction between apolipoprotein $E$ antiserum and serum (1), VLDL (2), or isolated apolipoprotein $E(3)$ as a function of the time.

100 fold diluted serum and apolipoprotein $E(0.085 \mathrm{~g} / \mathrm{l})$. and 50 fold diluted VLDL were mixed with a dilution of antibody solution as described. Light scattering was measured during $3 \mathrm{~h}$ at $23^{\circ} \mathrm{C}$.

The comparison of results obtained by immunonephelometry and electroimmunoassay (10 normal sèra and 10 hyperlipoproteinaemic sera) resulted in a good correlation between the 2 assays $(y \doteq 1.03 x-$ $0.06, r=0.93$ ). 


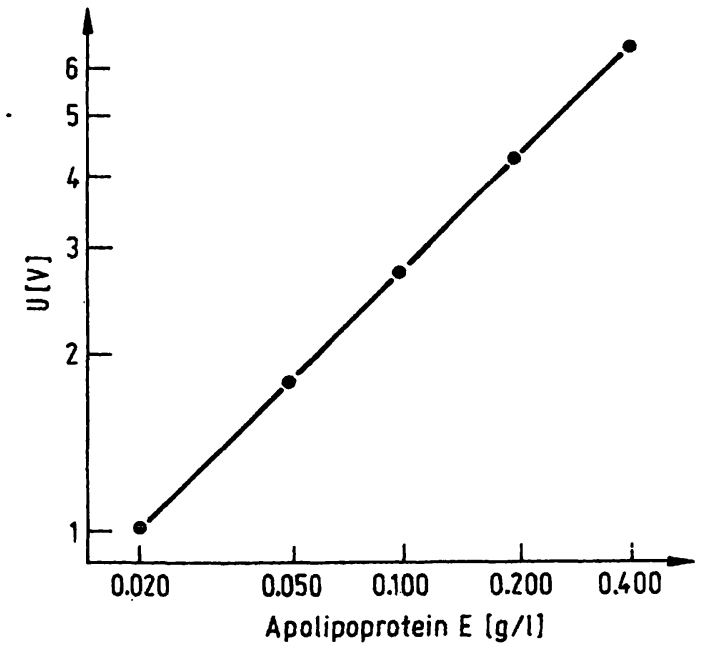

Fig. 2. Double-logarithmic plot of light scattering from isolated apolipoprotein E. Light scattering was measured after $2 \mathrm{~h}$ for apolipoprotein $\mathrm{E}(0.020-0.400 \mathrm{~g} / \mathrm{l})$ as described.

Tab. 1. Fasting serum apolipoprotein E concentration in normal and hyperlipoproteinaemic subjects.

\begin{tabular}{llll}
\hline Subjects & $\begin{array}{l}\text { Serum } \\
\text { cholesterol } \\
(\mathrm{g} / \mathrm{l})\end{array}$ & $\begin{array}{l}\text { Serum } \\
\text { triglycerides } \\
(\mathrm{g} / \mathrm{l})\end{array}$ & $\begin{array}{l}\text { Serum } \\
\text { apolipoprotein } \mathrm{E} \\
(\mathrm{g} / \mathrm{l})\end{array}$ \\
& $\begin{array}{l}\overline{\mathrm{x}} \pm \mathrm{SD} \\
\text { range }\end{array}$ & $\begin{array}{l}\overline{\mathrm{x}} \pm \mathrm{SD} \\
\text { range }\end{array}$ & $\begin{array}{l}\overline{\mathrm{x}} \pm \mathrm{SD} \\
\text { range }\end{array}$ \\
\hline Normal & $2.06 \pm 0.34$ & $0.75 \pm 0.19$ & $0.103 \pm 0.008$ \\
$(\mathrm{n}=20)$ & $1.38-2.61$ & $0.45-1.13$ & $0.084-0.118$ \\
Type II a & $3.96 \pm 1.48$ & $1.19 \pm 0.32$ & $0.113 \pm 0.011$ \\
$(\mathrm{n}=10)$ & $2.78-5.30$ & $0.76-1.49$ & $0.096-0.128$ \\
Type IIb & $3.12 \pm 0.59$ & $2.09 \pm 0.67$ & $0.109 \pm 0.008$ \\
$(\mathrm{n}=10)$ & $2.74-4.69$ & $1.64-3.56$ & $0.098-0.123$ \\
Type III & $5.69 \pm 0.30$ & $6.98 \pm 0.21$ & $0.426 \pm 0.022$ \\
$(\mathrm{n}=3)$ & $5.47-5.90$ & $6.90-7.06$ & $0.363-0.549$ \\
Type IV & $2.83 \pm 1.02$ & $5.82 \pm 3.82$ & $0.115 \pm 0.011$ \\
$(\mathrm{n}=10)$ & $2.07-4.93$ & $2.31-15.91$ & $0.097-0.132$ \\
\hline
\end{tabular}

\section{Apolipoprotein $E$ concentration in serum}

The serum apolipoprotein $\mathrm{E}$ levels in normal and hyperlipoproteinaemic subjects are summarized in table 1. The mean apolipoprotein $\mathrm{E}$ concentration of the normal subjects was $0.103 \pm 0.008 \mathrm{~g} / \mathrm{l}$. The mean in males $(n=8)$ did not differ from that in females $(n=12)$. Furthermore, the serum apolipoprotein $\mathrm{E}$ concentrations in Type II a, II b, and IV hyperlipoproteinaemias were similar to the normal values. As expected, the apolipoprotein E levels of the 3 patients with Type III hyperlipoproteinaemia were nearly 4 fold higher than the other ones.

\section{Distribution of apolipoprotein $E$ among lipoproteins}

The distribution of apolipoprotein E among VLDL and the $\mathrm{d}>1.006 \mathrm{~kg} / \mathrm{l}$ fraction after ultracentrifugation was investigated in normal and hyperlipoproteinaemic subjects (tab. 2). The portion of lipoproteinassociated apolipoprotein $\mathrm{E}$ found in VLDL was similar in normal and Type II subjects, while Type IV patients had an elevated apolipoprotein E content in this density range. In Type III patients separation of the lipoproteins by ultracentrifugation gave a still higher portion of VLDL apolipoprotein E in the other groups.

\section{Discussion}

This report describes the development and first application of a sensitive and specific assay for human apolipoprotein $\mathrm{E}$ in serum and lipoproteins using laser immunonephelometry. This technique, first applied to the assay of apolipoprotein B $(23,24)$, is more suitable for the handling of small as well as of large numbers of samples than other immunochemi-

Tab. 2. Distribution of apolipoprotein $E$ in VLDL $(d<1.006 \mathrm{~kg} / \mathrm{l})$ and in the $\mathrm{d}>1.006 \mathrm{~kg} /$ fraction.

\begin{tabular}{llllll}
\hline Subjects & $\begin{array}{l}\text { Serum cholesterol } \\
\text { (range) } \\
(\mathrm{g} / \mathrm{l})\end{array}$ & $\begin{array}{l}\text { Serum triglycerides } \\
\text { (range) } \\
(\mathrm{g} / \mathrm{l})\end{array}$ & $\begin{array}{l}\text { Serum apolipoprotein E } \\
\text { (range) } \\
(\mathrm{g} / \mathrm{l})\end{array}$ & $\begin{array}{l}\text { Percent distribution of apolipoprotein E in } \\
\text { lipoproteins of the density ranges }\end{array}$ \\
\hline $\begin{array}{l}\text { Normal } \\
(\mathrm{n}=6)\end{array}$ & $1.72-2.39$ & $0.90-1.88$ & $0.099-0.115$ & $\begin{array}{l}\mathrm{d}<1.006 \mathrm{~kg} / \mathrm{l} \\
\text { (range) }\end{array}$ & $\begin{array}{l}\mathrm{d}>1.006 \mathrm{~kg} / 1 \\
(\mathrm{range})\end{array}$ \\
$\begin{array}{l}\text { Type II } \\
(\mathrm{n}=5)\end{array}$ & $2.87-4.07$ & $1.04-3.02$ & $0.108-0.123$ & $22.2-28.9$ & $71.1-77.8$ \\
$\begin{array}{l}\text { Type III } \\
(\mathrm{n}=2)\end{array}$ & $5.47-5.90$ & $6.90-7.06$ & $0.363-0.549$ & $21.2-26.6$ & $73.4-78.8$ \\
$\begin{array}{l}\text { Type IV } \\
(\mathrm{n}=5)\end{array}$ & $2.16-3.55$ & $4.39-11.73$ & $0.097-0.132$ & $48.0-54.9$ & $45.1-52.0$ \\
\hline
\end{tabular}


cal assays. The precision of immunonephelometry fulfils the criteria required for standard procedures in clinical chemistry. Standardization of the method described is possible with isolated apolipoprotein $\mathrm{E}$. The serum apolipoprotein $E$ levels measured by laser immunonephelometry and electroimmunoassay were highly correlated, and each procedure was acceptable on the basis of its precision.

In assessing the serum apolipoprotein E concentration of normal subjects, we found values similar to that of Curry at al. (9) and Mackie et al. (13) using an electroimmunoassay and radioimmunoassay procedure respectively. Other authors published higher $(10)$ or lower $(8,11)$ absolute values of serum apolipoprotein $\mathrm{E}$. The discrepancies may be related to differences in apolipoprotein E preparations, antisera, and sample treatment procedures. In our study only Type III patients had distinctly elevated serum apolipoprotein $E$ levels, while other found elevated serum apolipoprotein $\mathrm{E}$ concentrations in servere hypertriglyceridaemia $(9,11)$ or hypercholesterolaemia(13) too. In some cases an incomplete catabolism of triglyceride-rich lipoproteins or unusual synthetic products may account for an increase of the serum apolipoprotein E concentration.

Our observation on the lipoprotein distribution of apolipoprotein $\mathrm{E}$ in normals is consistent with the data of the literature $(8-13)$. In agreement with Blum et al. (11), who used a radioimmunoassay technique, a shift to more VLDL-associated apolipoprotein E could be detected in Type IV hyperlipo= proteinaemia. In Type III hyperlipoproteinaemia about $50 \%$ of apolipoprotein $E$ is in the VLDL-density range. These findings must be evaluated in the light of the fact that the ultracentrifugation procedure results in the appearance of considerable amounts of apolipoprotein $\mathrm{E}$ in the lipoprotein-free fraction of serum $(11,13)$.

\section{Acknowledgements}

This work was supported by grants from the Deutsche Forschungsgemeinschaft (We 955/1-1).

\section{References}

1. Shore, V. G. \& Shore, B. (1973) Biochemistry 12, 502-507.

2. Weisgraber, K. H. \& Mahley, R. W. (1978) J. Biol. Chem. 253, 6218-6288.

3. Mahley, R. W. (1979) in: Atherosclerosis Review 5 (Paoletti, R. \& Gotto, A. M. jr., eds.) Raven Press, New York, N. Y., pp. $1-35$.

4. Sherrill, B. C., Innerarity, T. L. \& Mahley, R. W. (1980) J. Biol. Chem. 255, 1804-1807.

5. Goldstein, J. L., Ho, Y. K., Brown, M. S., Innerarity, T. L. \& Mahley, R. W. (1980) J. Biol. Chem. 255, 1839-1848.

6. Mahley, R. W., Hui, D. Y., Inneraity, T. L. \& Weisgraber, K. H. (1981) J. Clin. Invest. 68, 1197-1206.

7. Suarez, B. K. \& Schonfeld, G. (1981) J. Clin. Endocrinol. Metabolism 53, 435-438.

8. Havel, R. J., Kotite, L., Vigne, J.-L., Kane, J. P., Tun, P., Phillips, N. \& Chen, G. C. (1980) J. Clin. Invest. 66, 13511362.

9. Curry, M. D., McConathy, W. J., Alaupovic, P., Ledford, J. H. \& Popović, M. (1976) Biochim. Biophys. Acta 439, 413425.

10. Kushwaha, R. S., Hazzard, W. R., Wahl, P. W. \& Hoover, J. J. (1977) Ann. Int. Med. 87, 509-516.

11. Blum, C. B.. Aron, L. \& Sciacca, R. (1980) J. Clin. Invest. $66,1240-1250$.

12. Milne, R. W., Douste-Blazy, P., Marcel, Y. L. \& Retegui, L. (1981) J. Clin. Invest. 68, 111-117.
13. Mackie, A., Caslake, M. J., Packard, C. J. \& Shepherd, J. (1981) Clin. Chim. Acta 116, 35-45.

14. Conrad, A., Schürmann, J. Kreutz, F. H. \& Sieber, A. (1978) J. Clin. Chem. Clin. Biochem. 16, 229=231.

15. Havel, R. J.; Eder, H. A. \& Bragdon, J. H. (1955) J. Clin. Invest. 34, 1345-1353.

16. Lopes-Virella, M. F., Stone, P., Ellis, S. \& Colwell, A. (1977) Clin. Chem. 23, 882-884.

17. Beaumont, J. L., Carlson, L. A., Cooper, G. R., Fejfar, Z., Fredrickson, D. S., Strasser, T. (1970) Bull. Wld. Hlth. Org. 43, 891-915.

18. Görg, A., Postel, W., Westermeier, R., Gianazza, E. \& Righetti, P. G. (1980) J. Biochem. Biophys. Meth. 3, 273-284

19. Weisweiler, P. \& Schwandt, P. (1982) Clin. Chim. Acta 124, 45-50.

20. Weber, K. \& Osborn, M. (1969) J. Biol. Chem. 244, 44064412.

21. Lowry, O. H., Rosebrough, N. J., Farr, A. L. \& Randall, R. J. (1.951) J. Biol. Chem. 193, 265-275.

22. Weisweiler, P. \& Schwandt, P. (1980) Fresenius Z. Arial. Chem. 301, 157-158.

23. Ballantyne, F. C., Williamson, J., Shapiro, D., Caslake, M. J., Perry, B. (1978) Clin. Chem. 24, 788-792.

24. Heuck, C. C. \& Schlierf, G. (1979) Clin. Chem. 25, 221226.
Dr. med. 'Peter Weisweiler

Medical Department II

Grosshadern Clinic

University of Munich

Marchioninistrasse 15

D-8000 Muñich 